nuevas publicaciones en biblioteca FAU 2007

Presentamos algunas de las publicaciones que han llegado a nuestra revista y a nuestra biblioteca.

Agradecemos la consideración para con nuestro proyecto editorial.
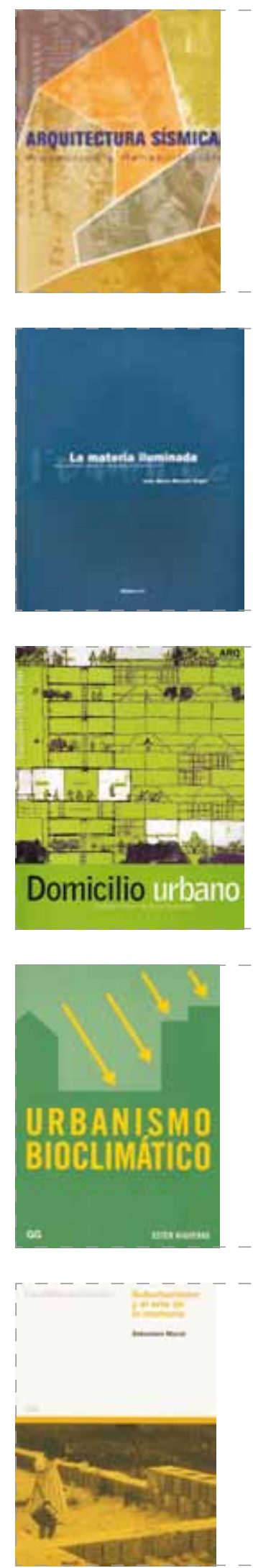
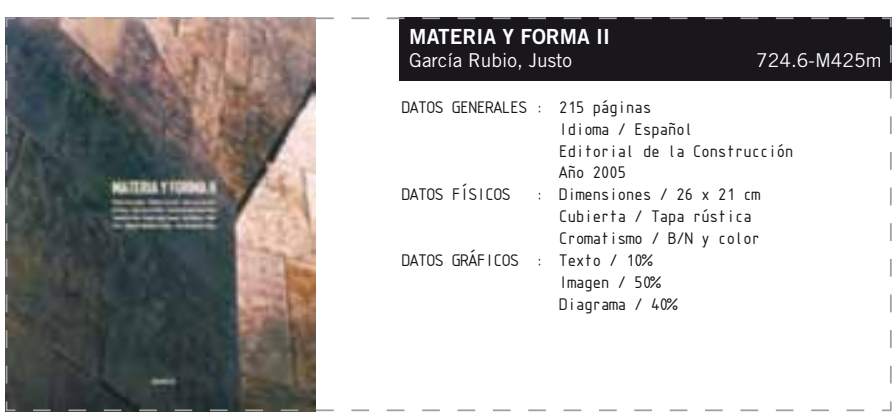

\section{ARQUITECTURA SÍSMICA}

DATOS GENERALS

208 páginas

Idioma / Españo

datos Físicos

Aก̃o 2000

Cubierta / Tapa dura y sobrecubierta Cromat ismo / color

Texto / $15 \%$ Díagrama / $35 \%$

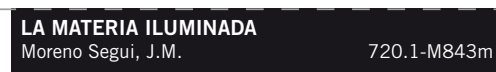

Dotos geveres:

Idioma / Español

DAtos Físicos : Año 2002 Dimensiones $/ 35,5 \times 21 \mathrm{~cm}$

Cubierta / Tapa rústica

DATOS GRÁFILOS

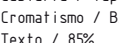

Imagen / 10\%

Diagrama / $50 \%$

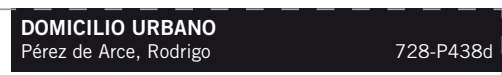

DATOS GenERALES : 209 páginas

Idioma / Español
Editorial ARQ

Editorial ARQ
Año 2006

DATOS FísICOS : Año 2006

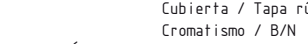

DATOS GŔ́fIICOS : Texto / $65 \%$

Imagen / $25 \%$
Diagrama $/ 10 \%$

\section{URBANISMO BIOCLIMÁTICO
Higueras, Ester}

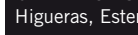

Gotos Gerepats :

242 páginas

Idioma / Español

Año 2006

DATOS Físicos

Año 2006

Mimens iones $/ 24 \times 17 \mathrm{~cm}$
ubierta / Tapa rústica

Cromat ismo o / B

DATOS GRÁFICOS : Texto / $65 \%$

Imagen / 10\%
Di agrama / 25\%

\subsection{6-H634u}

\section{SUBURBANISMO Y EL ARTE DE LA MEMORIA}

\section{Marot, Sebastien}

DATOS GENERALES : 152 pági inas

IS2 paginas
Idioma / Español

Editorial Gustavo Gili

DATOS Físicos : Año 2006 Dimensiones $/ 21 \times 14,9$ cm Cubierta / Tapa rústica

DATOS GRÁfIICOS: Texto / $60 \%$

Inagen $/ 25 \%$
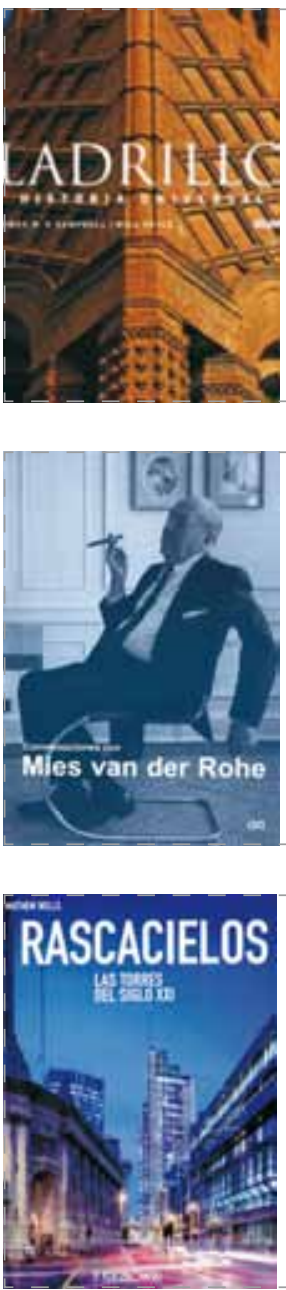

\section{RASCACIELOS: LAS TORRES DEL SIGLO XXI
Wells, Matthew}

$\begin{aligned} \text { DATOS GENERALES : } & 192 \text { páginas } \\ & \text { Idioma I/ Españal }\end{aligned}$

lationa / Español

Año 2005

DATOS Físicos : Dimensiones / $31 \times 21,8 \mathrm{~cm}$ cubierta / Tapa dura y sobrecubiert

DATOS GRÁFI ICOS : Cromati ismo Imagen / $60 \%$
Diagrama / $10 \%$

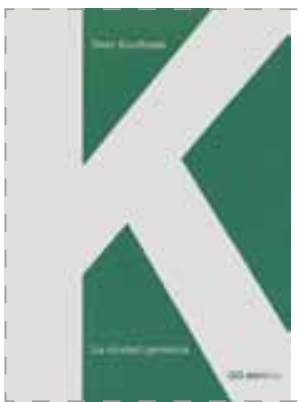

\section{LA CIUDAD GENÉRICA}

Koolhaas, Rem

DATOS GeNERALES : 62 páginas Idioma / Español Editorial Gustavo Gili

DAtos Físicos : Aiñ 2006 Dimensiones / 16,5 12,2 cm Cubierta / Tapa rústica

DATOS GPÁFICOS - Tromat ismo Texto
Imagen / $/ 0 \%$ 